\title{
EFFECTS OF IMPURITIES FROM PHOSPHOGYPSUM ON THE CRYSTAL GROWTH OF CALCIUM SULFATE HEMIHYDRATES
}

\author{
VPLIV NEČISTOČ KALCIJEVEGA FOSFATA (SADRE) NA RAST \\ KRISTALOV KALCIJEVEGA SULFAT-POLHIDRATA
}

\author{
Hongbin Tan ${ }^{1,2,3 *}$, Faqin Dong ${ }^{3 * *}$, Jinfeng Liu' ${ }^{1}$, Jin Wang1, Xiaochun $\mathrm{He}^{1}$ \\ ${ }^{1}$ Southwest University of Science and Technology, School of Materials Science and Engineering, State Key Laboratory of \\ Environment-friendly Energy Materials, Qinglong Road 59, Mianyang 621010, China \\ ${ }^{2}$ Shaanxi University of Technology, Shaanxi Engineering Center of Metallurgical Sediment Resource, Hanzhong Shaanxi 723000, China \\ ${ }^{3}$ Southwest University of Science and Technology, Ministry of Education, Key Laboratory of Solid Waste Treatment and Resource Recycle, \\ Qinglong Road 59, Mianyang Sichuan 621010, China \\ *hb-t@163.com (H. Tan),**fqdong@swust.edu.cn (F. Dong) \\ Prejem rokopisa - received: 2018-04-24; sprejem za objavo - accepted for publication: 2018-05-10
}

doi:10.17222/mit.2018.082

\begin{abstract}
The influences of organic compounds, supernatant, calcium phosphate and calcium fluoride on the morphology of calcium sulfate hemihydrate were investigated in hydrothermal conditions by using calcium sulphate dihydrate of analytical grade as the raw material, while the organic compounds and supernatant were obtained from phosphogypsum (PG). The influence of the supernatant on the crystal growth was greater than the organic compounds. The crystal diameter increased and the aspect ratio decreased, while the added amounts of calcium fluoride and calcium phosphate increased. The influence of calcium phosphate on the crystal growth was more obvious than with calcium fluoride. Extremely non-uniform whiskers were observed when the amount of calcium fluoride and calcium phosphate were $5 \%$ and $3 \%(w / \%)$, respectively.

Key words: phosphogypsum; calcium sulfate hemihydrate; crystal morphology; impurities
\end{abstract}

Avtorji so v pričujočem prispevku raziskovali vplive organskih spojin, plavajočih ostankov, kalcijevega sulfata in kalcijevega fluorida na morfologijo kalcijevega sulfat polhidrida v hidrotermalnih pogojih. Kot surovino so uporabili sulfat dihidrat analitične čistosti. S to sintezo so dobili organske spojine in plavajoče ostanke iz fosfatnega gipsa (PG). Vpliv plavajočih ostankov na rast kristalov je bil večji kot vpliv organskih spojin. Premer kristalov je naraščal, medtem ko je razmerje med dolžino in premerom kristalov padalo z naraščanjem dodatka kalcijevega fluorida oz. kalcijevega fosfata. Vpliv kalcijevega fosfata na rast kristalov je bil očitnejši kot vpliv jedavca (kalcijevega fluorida). Vlakna skrajno nepravilnih oblik so nastajala, ko je bila vsebnost kalcijevega fluorida in kalcijevega fosfata $5 \%$ oz. $3 \%$.

Ključne besede: fosfatni gips (sadra), kalcijev sulfat polhidrat, kristalna morfologija, nečistoče

\section{INTRODUCTION}

Phosphogypsum (PG) is a major solid waste when phosphoric acid $\left(\mathrm{H}_{3} \mathrm{PO}_{4}\right)$ is manufactured using a wet acid process, of which gypsum $\left(\mathrm{CaSO}_{4} \cdot 2 \mathrm{H}_{2} \mathrm{O}\right)$ is the major component. ${ }^{1}$ About $4.5-5 \mathrm{~kg}$ of $\mathrm{PG}$ is generated for every $\mathrm{kg}$ of $\mathrm{P}_{2} \mathrm{O}_{5}$ produced. Almost 55 million tons of PG are generated annually in China and its output is estimated to be around 280 million tons worldwide per year. ${ }^{2,3}$ Currently, PG is applied in fields, as soil-stabilization amendments, agricultural fertilizers, cement retarders, building bricks/blocks and cementitious binders. ${ }^{3,4}$ However, the reuse proportion of PG is lower than $10 \%$, while the vast majority of $\mathrm{PG}$ is dumped in large stockpiles, which are exposed to weathering processes without any treatment. ${ }^{3}$ PG contains metals, organic substances and other potentially toxic elements, which have potential environmental impacts. ${ }^{5}$ Therefore, the effective utilization of PG cannot only save the natural gypsum, but protect the environment. ${ }^{6}$ It will be of interest to see the transformations of PG to obtain high-value-added gypsum products. $^{7}$
Although six different gypsum phases are known, only anhydrous calcium sulfate $\left(\mathrm{AH}, \mathrm{CaSO}_{4}\right)$, calcium sulfate hemihydrate $\left(\mathrm{HH}, \mathrm{CaSO}_{4} \cdot 0.5 \mathrm{H}_{2} \mathrm{O}\right)$, and calcium sulphate dihydrate $\left(\mathrm{DH}, \mathrm{CaSO}_{4} \cdot 2 \mathrm{H}_{2} \mathrm{O}\right)$ are the usually encountered three phases. ${ }^{6}$ Among gypsum products, $\mathrm{HH}$ crystals have high economic value and have been widely utilized.

Recently, much more attention has been paid to the morphological control of $\mathrm{HH}$ crystals, since many applications are dependent on the crystal morphology. ${ }^{8}$ For example, acicular HH crystals (whiskers) are widely used as the reinforcing agent in many fields, such as in rubbers, plastics, adhesives, friction materials, papermaking and environmental protection. ${ }^{9-11}$ Short columnar crystals are used as a cementitious material for its superior workability and high strength, such as in ceramics, molding, special binder systems, industrial arts and architecture, as well as in the construction industry. ${ }^{7}$

The morphology of $\mathrm{HH}$ is usually influenced by process parameters and organic/ inorganic additives..$^{12-14}$

$\mathrm{Han}$ et al. investigated the influence of $\mathrm{Na}_{2} \mathrm{HPO}_{4} \cdot 12 \mathrm{H}_{2} \mathrm{O}$ on the hydrothermal formation of $\mathrm{HH}$ 
whiskers from calcium sulfate dihydrate $\left(\mathrm{CaSO}_{4} \cdot 2 \mathrm{H}_{2} \mathrm{O}\right)$ at $135{ }^{\circ} \mathrm{C} .{ }^{15}$ They observed that $\mathrm{HH}$ whiskers were prepared at $135{ }^{\circ} \mathrm{C}$ for $2 \mathrm{~h}$ by adding $8.72 \times 10^{-3} \mathrm{~mol} / \mathrm{L}$ $\mathrm{Na}_{2} \mathrm{HPO}_{4} \cdot 12 \mathrm{H}_{2} \mathrm{O}$. When the $\mathrm{P}_{2} \mathrm{O}_{5}$ content was more than $0.6 \%$, it was difficult to obtain thin and high-aspect-ratio whiskers. ${ }^{16} \mathrm{He}$ et al. prepared $\mathrm{HH}$ whiskers in glycerol solution, where the glycerol plays an important role in promoting the dissolution of $\mathrm{CaSO}_{4} \cdot 2 \mathrm{H}_{2} \mathrm{O}$ and guiding the growth of $\mathrm{CaSO}_{4} \cdot 0.5 \mathrm{H}_{2} \mathrm{O}$ whiskers along the c-axis. ${ }^{6}$

The PG usually contains P, F, and organic compounds, which will affect the morphology of $\mathrm{HH}$. But the details need to determined. In this work, the influences of organic compounds and the supernatant of PG, calcium phosphate and calcium fluoride on the morphology of $\mathrm{HH}$ were investigated.

\section{EXPERIMENTAL PART}

Commercial calcium sulphate dihydrate, calcium phosphate, calcium fluoride and sulphuric acid of analytical grade were provided by Chengdu Kelong Chemical Reagent Co. Ltd., China. PG was provided by Guangxi Luzhai Chemical fertilizer Co. Ltd., China.

The X-ray diffraction (XRD) pattern and chemical composition of the as-received PG are shown in Figure 1 and Table 1, respectively. The PG contained $50.37 \%$ of mass fractions of $\mathrm{SO}_{3}, 39.60 \% \mathrm{CaO}, 7.99 \% \mathrm{SiO}_{2}$, $1.07 \% \quad \mathrm{P}_{2} \mathrm{O}_{5}$, etc. The $\mathrm{PG}$ phases were mainly $\mathrm{CaSO}_{4} \cdot 2 \mathrm{H}_{2} \mathrm{O}(85.68 \%)$, a minor amount of poorly crystalline $\mathrm{CaSO}_{4} \cdot 0.5 \mathrm{H}_{2} \mathrm{O}$, and crystalline $\mathrm{SiO}_{2}$.

A $100 \mathrm{~g}$ of PG was added to $2000 \mathrm{~mL}$ of water and stirred to obtain an organic compounds foam. The organics mainly came from the floatation reagent of phos- phorite, where the floatation reagent is a surface-active agent. The supernatants were obtained from leaching PG for $(2,4$ and 6$) \mathrm{h}$. The chemical compositions of the supernatants are shown in Table 2, where the supernatants contained some impurities (e.g., P, F, Na, etc). The iron content was almost unchanged, while the leaching time increased.

Table 1 Chemical composition of PG (w/\%)

\begin{tabular}{|c|c|c|c|c|c|c|c|c|}
\hline $\mathrm{CaO}$ & $\mathrm{SO}_{3}$ & $\mathrm{SiO}_{2}$ & $\mathrm{P}_{2} \mathrm{O}_{5}$ & $\mathrm{Al}_{2} \mathrm{O}_{3}$ & $\mathrm{Fe}_{2} \mathrm{O}_{3}$ & $\mathrm{~K}_{2} \mathrm{O}$ & $\mathrm{SrO}$ & $\mathrm{MgO}$ \\
\hline 39.60 & 50.37 & 7.99 & 1.07 & 0.51 & 0.21 & 0.13 & 0.08 & 0.04 \\
\hline
\end{tabular}

The FT-IR spectra of the organics foam and the supernatants are shown in Figure 2. It is clear that the bands at $3270 \mathrm{~cm}^{-1}$ and $1639 \mathrm{~cm}^{-1}$ are assigned to the $\mathrm{OH}$ of the water stretching modes and bending modes, respectively. The band at $1120 \mathrm{~cm}^{-1}$ can be assigned to the organics stretching or bending modes. The band at $400 \mathrm{~cm}^{-1}$ can be assigned to the hydrated ion stretching or bending modes.

$2.0 \mathrm{~g} \mathrm{DH}$ and $40 \mathrm{~mL}$ water/supernatant were added into a 50-mL Teflon stainless-steel autoclave. To some of solution, calcium phosphate, calcium fluoride or the organics were added. The reaction systems were stirred with a glass rod, and then aged at $140^{\circ} \mathrm{C}$ for $2 \mathrm{~h}$. Finally, the autoclaves were cooled down to room temperature naturally, and the samples were filtered and then washed with hot distilled water and dried at $100{ }^{\circ} \mathrm{C}$ for $5 \mathrm{~h}$.

The morphologies of samples were characterized by scanning electron microscopy (SEM, TM-1000, Hitachi, Japan). The phases of the PG and the samples were identified by X-ray powder diffraction (XRD) (X'pert $\mathrm{PRO}$, PANalytical, Netherlands) using $\mathrm{Cu}-K_{\alpha}$ radiation

Table 2 Chemical compositions of the supernatants (mg/L)

\begin{tabular}{|c|c|c|c|c|c|c|c|c|c|c|c|c|}
\hline Leaching time $(\mathrm{h})$ & $\mathrm{As}$ & $\mathrm{Ca}$ & $\mathrm{K}$ & $\mathrm{Mg}$ & $\mathrm{Mn}$ & $\mathrm{Na}$ & $\mathrm{P}$ & $\mathrm{Si}$ & $\mathrm{Sr}$ & $\mathrm{F}$ & $\mathrm{Cl}$ \\
\hline 2 & 0.16 & 371.28 & 8.53 & 7.39 & 0.641 & 17.79 & 2.14 & 1.49 & 2.54 & 0.26 & 10.27 \\
\hline 4 & 0.16 & 322.70 & 8.50 & 7.25 & 0.59 & 16.74 & 2.04 & 1.25 & 2.25 & 0.27 & 10.29 \\
\hline 6 & 0.18 & 311.10 & 8.27 & 10.08 & 0.63 & 16.90 & 2.46 & 1.30 & 2.40 & 0.21 & 10.29 \\
\hline
\end{tabular}

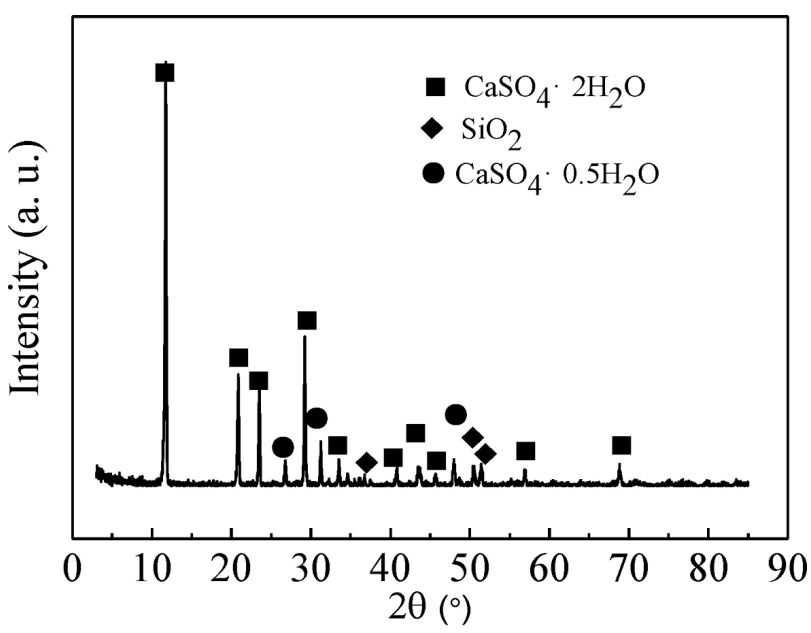

Figure 1: XRD pattern of received PG

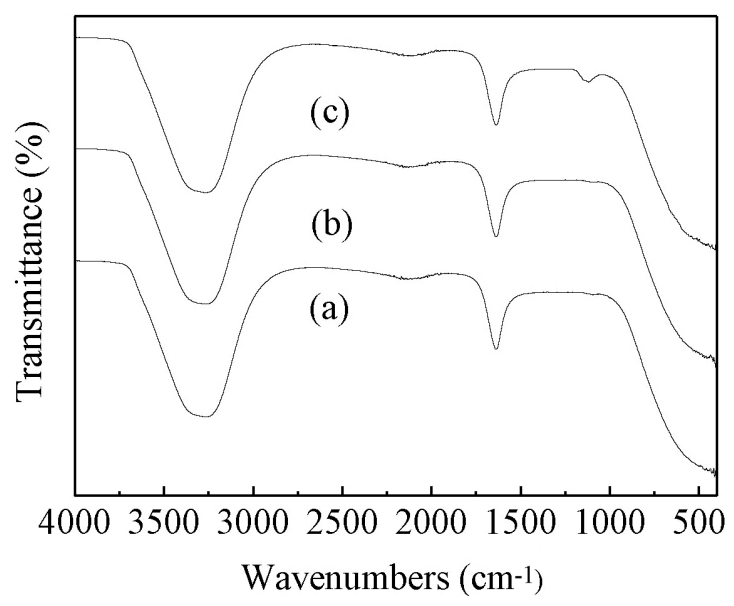

Figure 2: FT-IR spectra of the supernatant leached for: a) 2 h, b) $6 \mathrm{~h}$ and c) the organics foam of PG 

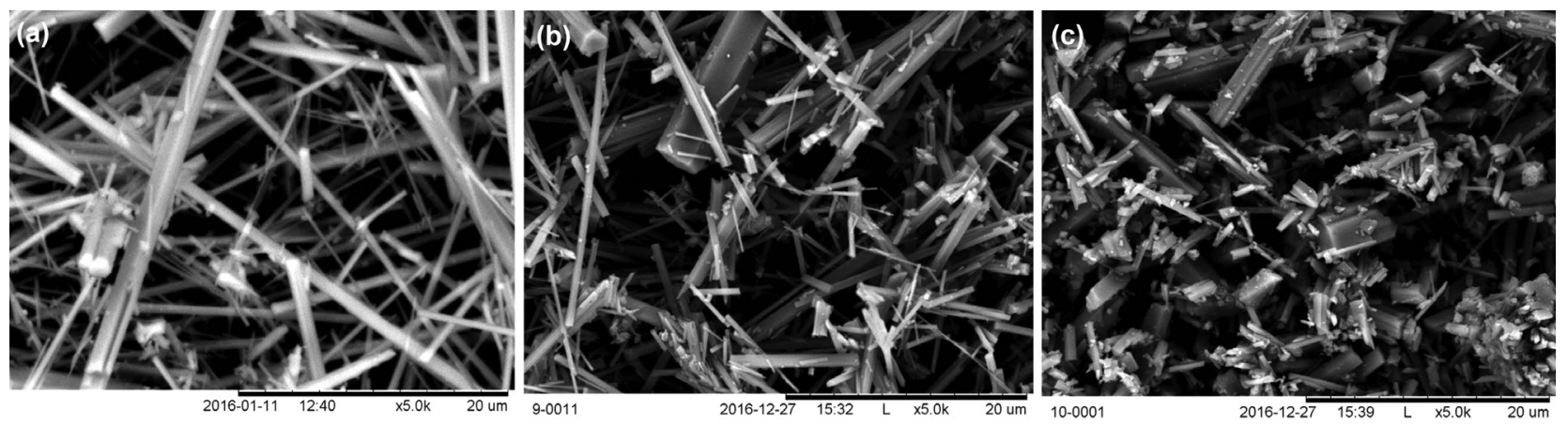

Figure 3: SEM micrographs of the samples prepared with/without PG impurities: a) without the impurities, b) with the organics foam, c) with the supernatant

$(k=0.154178 \mathrm{~nm})$. The chemical compositions of the supernatants were tested with an ion chromatograph (Compact IC pro 881, Metrohm, Switzerland) and inductively coupled plasma atomic emission spectroscopy (ICP) (ICAP 6500, ThermofiShher scientific, UK).

\section{RESULTS AND DISCUSSION}

\section{(1) Effects of PG impurities on the crystal growth}

The SEM micrographs of the samples prepared with/without PG impurities are shown in Figure 3. The $\mathrm{HH}$ whiskers were obtained without the addition of PG impurities (Figure 3a), with a $0.5-1.5 \mu \mathrm{m}$ diameter and a 30-40 aspect ratio.

The formation mechanism of calcium sulfate hemihydrates whiskers was a dissolution-recrystallization. The formation of the whiskers underwent a three-stage process. Firstly, the homogeneous nucleation of calcium sulfate hemihydrate took place; secondly, self-assembly of calcium sulfate hemihydrate aggregated co-oriented along their c axes; finally, the crystalline grain grown occurred and the whiskers formed. ${ }^{17} \mathrm{Cal}-$ cium sulfate hemihydrate normally crystallizes in the whiskers (1D shape) because the crystal lattice of calcium sulfate hemihydrate consists of $-\mathrm{SO}_{4}-\mathrm{Ca}-\mathrm{SO}_{4}-\mathrm{Ca}-$ chains, with each $\mathrm{S}$ atom and four $\mathrm{O}$ atoms forming a tetrahedron. These chains are hexagonally arranged and form a framework parallel to the c axis, where one water molecule is attached to every two calcium sulfate molecules. ${ }^{18}$

The $\mathrm{HH}$ whiskers were obtained by adding organics, where the organics were obtained by adding PG to water and stirring to produce the organics foam. The $\mathrm{HH}$ crystals were obtained with about $0.2-4 \mu \mathrm{m}$ diameter and an about 10-20 aspect ratio (Figure 3b).

The HH whiskers were obtained by adding supernatant, where the supernatant was obtained by leaching PG. The HH crystals were obtained with $0.2-4 \mu \mathrm{m}$ in diameter and an about 1-6 aspect ratio (Figure 3c).

The mechanism of impurities on the crystal morphology control as through selective adsorption on specific crystal planes to alter their surface energy. During the hydrothermal process, the impurity molecules tend to absorb on the polar crystal faces rather than on the prismatic faces, which would inhibit the crystal growth along the plane. ${ }^{15-18}$

According to the above results, the influence of the supernatant on the $\mathrm{HH}$ crystal growth was greater than the organics. In these impurities, $\mathrm{PO}_{4}{ }^{3-}$ and $\mathrm{F}^{-}$can react with $\mathrm{Ca}^{2+}$ to form difficult-to-dissolve compounds $\left(\mathrm{Ca}_{3}\left(\mathrm{PO}_{4}\right)_{2}, \mathrm{CaF}_{2}\right)$, which can firmly adsorb on the $\mathrm{HH}$ crystal surfaces and hinder the crystal growth. On the other hand, the impurity compounds were also possibly the crystal nucleus for the $\mathrm{HH}$ and influenced the $\mathrm{HH}$ crystal growth.

\section{(2) Effects of calcium fluoride/calcium phosphate on the crystal growth}

The SEM micrographs of the samples prepared by adding calcium fluoride are shown in Figure 4. The
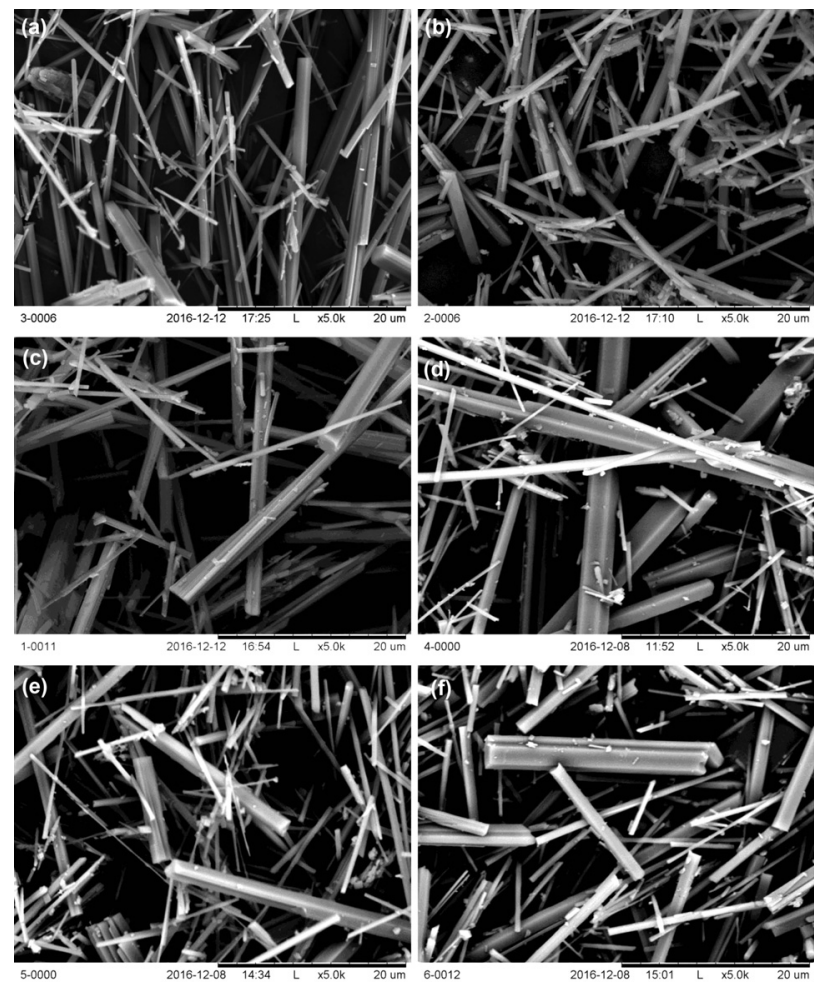

Figure 4: SEM micrographs of the samples prepared by adding calcium fluoride: a) $0.5 \%$, b) $1.0 \%$, c) $3.0 \%$, d) $5.0 \%$, e) $10.0 \%$, f) $15.0 \%$ 
influence on the crystal growth was little by adding a $0.5 \%$ calcium fluoride. The diameter increased and the aspect ratio decreased, while the addition amount of calcium fluoride increased. The crystals were obtained by adding $15 \%$ of mass fractions of calcium fluoride, with $0.5-3.5 \mu \mathrm{m}$ diameter and a 6-30 aspect ratio.

The SEM micrographs of the samples prepared by adding calcium phosphate are shown in Figure 5. The crystals, with a 15-30 aspect ratio and a 0.6-2.0 $\mu \mathrm{m}$ diameter were obtained by adding $0.5 \%$ calcium phosphate. And some short crystals were also observed. Some particles of calcium sulfate were observed by adding $1.0 \%$ calcium phosphate. The crystals were obtained by adding $15 \%$ calcium phosphate, with 1.0-3.5 $\mu \mathrm{m}$ diameter and a $4-10$ aspect ratio.

The $\mathrm{pK}_{\mathrm{sp}}$ of calcium sulphate dihydrate, calcium fluoride and calcium phosphate are 6.29, 9.79 and 28.70, respectively. The dissolved $\mathrm{PO}_{4}{ }^{3-}$ to from the calcium phosphate can absorb on the crystal surface and hinder the crystal growth. The dissolved $\mathrm{F}^{-}$to from the calcium fluoride can also absorb on the crystal surface and hinder the crystal growth. The influence of calcium fluoride on the crystal growth was not more obvious than calcium phosphate, because the solubility of the calcium fluoride is higher than the calcium phosphate.

On the other hand, extremely un-uniform whiskers can be observed when the amount of calcium fluoride was $5 \%$ and the amount of calcium phosphate was $3 \%$.
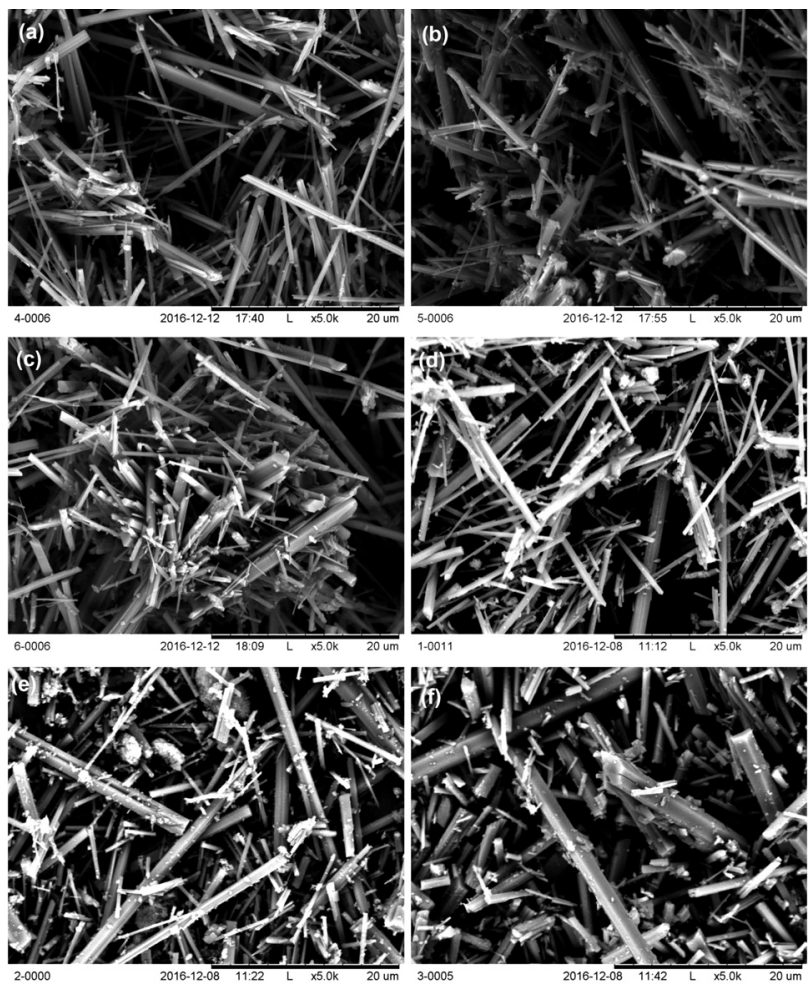

Figure 5. SEM micrographs of the samples prepared by adding calcium phosphate: a) $0.5 \%$, b) $1.0 \%$, c) $3.0 \%$, d) $5.0 \%$, e) $10.0 \%$ f) $15.0 \%$

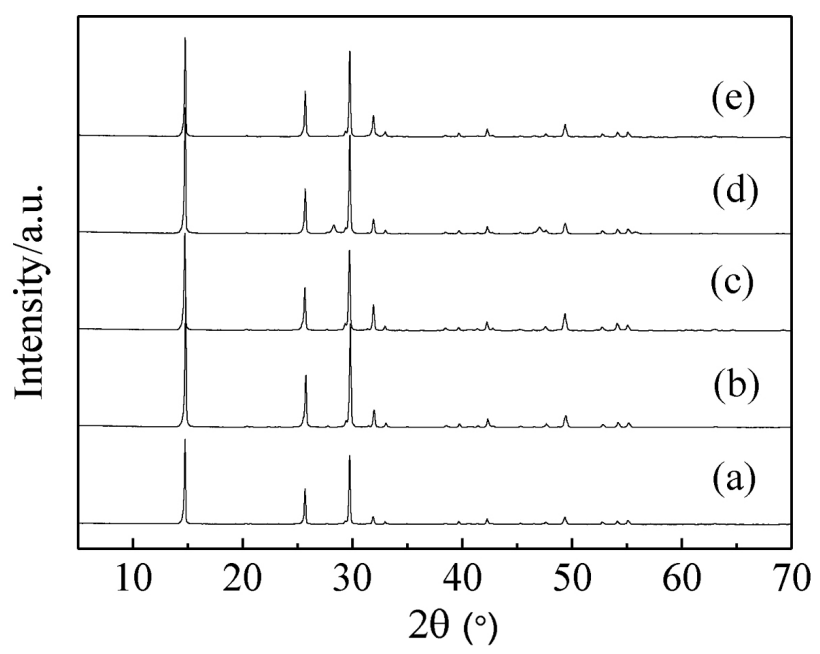

Figure 6. XRD patterns of the samples prepared: a) without the impurities, with b) the organics form, c) the supernatant d) calcium fluoride and e) calcium phosphate

The XRD patterns of the samples prepared without, with the organics, the supernatant, calcium fluoride and calcium phosphate are shown in Figure 6. The peaks of the samples presented analogous diffraction angles, indicating that the phases of all the samples were same calcium sulfate hemihydrate $\left(\mathrm{CaSO}_{4} \cdot 0.5 \mathrm{H}_{2} \mathrm{O}\right)$. The peaks of calcium phosphate and calcium fluoride were not obvious, because the peaks were much weaker than the HH peaks.

According to the above result, the HH crystal growth was most affected by the soluble phosphorus of the supernatant. The soluble phosphorus can be removed by using water to wash the PG. ${ }^{6}$ The effect of soluble phosphorus on the crystal growth can also be decreased by adding $\mathrm{CaO}$ in the $\mathrm{PG} .{ }^{16}$

\section{CONCLUSIONS}

The HH crystals were obtained by adding organics with an about $0.2-4 \mu \mathrm{m}$ diameter and an about 10-20 aspect ratio. The $\mathrm{HH}$ crystals were obtained by adding the supernatant, with a $0.2-4 \mu \mathrm{m}$ diameter and an about 1-6 aspect ratio. The influence of the supernatant on the HH crystals' growth was greater than the organics.

The crystal diameter increased and aspect ratio decreased when the added amount of calcium fluoride and calcium phosphate increased, respectively. The influence of calcium phosphate on the crystal growth was more obvious than the calcium fluoride. Extremely non-uniform whiskers can be observed when the amounts of calcium fluoride and calcium phosphate were 5 and $3 \%(w / \%)$, respectively.

\section{Acknowledgements}

This work was supported by the Sichuan Science and Technology Development Program of China 
(2017GZ0380) and Natural Science Foundation of Southwest University of Science and Technology (18zx7101).

\section{REFERENCES}

${ }^{1}$ O. Hentati, N. Abrantesd, A. L. Caetano, S. Bouguerra, F. Gonçalves, J. Römbkeg, R. Pereira, Phosphogypsum as a soil fertilizer: Ecotoxicity of amended soil and elutriates to bacteria, invertebrates, algae and plants, J. Hazar. Mater., 294 (2015), 80-89, doi:10.1016/j.jhazmat.2015.03.034

${ }^{2}$ M. Contreras, R. Pérez-López, M. J. Gázquez, V. Morales-Flórez, A. Santos, L. Esquivias, J. P. Bolívar, Fractionation and fluxes of metals and radionuclides during the recycling process of phosphogypsum wastes applied to mineral $\mathrm{CO}_{2}$ sequestration, Waste Manage., 45 (2015), 412-419, doi:10.1016/j.wasman.2015.06.046

${ }^{3}$ Y. Shen, J. Qian, J. Chai, Y. Fan, Calcium sulphoaluminate cements made with phosphogypsum: Production issues and material properties, Cem. Concr. Compos., 48 (2014), 67-74, doi:10.1016/ j.cemconcomp.2014.01.009

${ }^{4} \mathrm{M}$. Zielinski, Influence of constant magnetic field on the properties of waste phosphogypsum and fly ash composites, Constr. Build. Mater., 89 (2015), 13-24, doi:10.1016/j.conbuildmat.2015.04.029

${ }^{5}$ A. A. Cuadri, F. J. Navarro, M. García-Morales, J.P. Bolívar, Valorization of phosphogypsum waste as asphaltic bitumen modifier, J. Hazar. Mate., 279 (2014), 11-16, doi:10.1016/j.jhazmat.2014.06.058

${ }^{6} \mathrm{H}$. He, F. Dong, P. He, L. Xu, Effect of glycerol on the preparation of phosphogypsum-based $\mathrm{CaSO}_{4} \cdot 0.5 \mathrm{H}_{2} \mathrm{O}$ whiskers, J. Mater. Sci., 49 (2014), 1957-1963, doi.10.1007/s10853-013-7825-4

${ }^{7}$ B. Guan, L. Yang, H. Fu, B. Kong, T. Li, L.Yang, $\alpha$-calcium sulfate hemihydrate preparation from FGD gypsum in recycling mixed salt solutions, Chem. Eng. J., 174 (2011), 296-303, doi:10.1016/ j.cej.2011.09.033

${ }^{8}$ X. Mao, X. Song, G. Lu, Y. Xu, Y. Sun, J. Yu, Effect of additives on the morphology of calcium sulfate hemihydrate: Experimental and molecular dynamics simulation studies, Chem. Eng. J., 278 (2015), 320-327, doi:10.1016/j.cej.2014.10.006

${ }^{9}$ X. Feng, Y. Zhang, G. Wang, M. Miao, L. Shi, Dual-surface modification of calcium sulfate whisker with sodium hexametaphos- phate/silica and use as new water-resistant reinforcing fillers in papermaking, Powder Tech., 271 (2015), 1-6, doi:10.1016/j.powtec. 2014.11.015

${ }^{10}$ Z. Zhu, L. Xu, G. Chen, Effect of different whiskers on the physical and tribological properties of non-metallic friction materials, Mater. Des., 32 (2011), 54-61, doi:10.1016/j.matdes.2010.06.037

${ }^{11}$ X. Chen, L. Yang, J. Zhang, Y. Huang, Exploration of As(III)/As(V) uptake from aqueous solution by synthesized calcium sulfate whisker, Chin. J. Chem. Eng., 22 (2014), 1340-1346, doi:10.1016/ j.cjche.2014.09.018

${ }^{12}$ C. Hazra, S. Bari, D. Kundu, A. Chaudhari, S. Mishra, A. Chatterjee, Ultrasound-assisted/biosurfactant-templated size-tunable synthesis of nano-calcium sulfate with controllable crystal morphology, Ultrason. Sonochem., 21 (2014), 1117-1131, doi:10.1016/j.ultsonch.2013. 12.020

${ }^{13}$ J. Mao, G. Jiang, Q. Chen, B. Guan, Influences of citric acid on the metastability of $\alpha$-calcium sulfatehemihydrate in $\mathrm{CaCl}_{2}$ solution, Coll. Surf. A: Phys. Eng. Aspects, 443 (2014), 265-271, doi:10.1016/j.colsurfa.2013.11.023

${ }^{14}$ B. Kong, J. Yu, K. Savino, Y. Zhu, B. Guan, Synthesis of $\alpha$-calcium sulfate hemihydrate submicron-rods in water/n-hexanol/CTAB reverse microemulsion, Coll. Surf. A: Phys. Eng. Aspects, 409 (2012), 88-93, doi:10.1016/j.colsurfa.2012.05.041

${ }^{15}$ Q. Han, K. Luo, H. Li, L. Xiang, Influence of disodium hydrogen phosphate dodecahydrate on hydrothermal formation of hemihydrate calcium sulfate whiskers, Particuology, 17 (2014), 131-135, doi:10.1016/j.partic.2013.10.002

${ }^{16}$ F. Dong, Z. Huang, H. Tan, C. Wu, P. He, Effect of additives on calcium sulfate hemihydrate whiskers morphology from calcium sulfate dehydrate and phosphogypsum, Mater. Manuf. Process, 31 (2016), 2037-2043, doi:10.1080/10426914.2016.1176184

${ }^{17}$ F. Li, J. Liu, G. Yang, Z. Pan, X. Ni, H. Xu, Q. Huang, Effect of pH and succinic acid on the morphology of $\alpha$-calcium sulfate Hemihydrate synthesized by a salt solution method, J. Crys. Grow., 374 (2013), 31-36, doi:10.1016/j.jcrysgro.2013.03.042

${ }^{18}$ Y.-W. Wang, C. Meldrum, Additives stabilize calcium sulfate hemihydrate (bassanite) in solution, J. Mater. Chem., 22 (2012), 22055-22062, doi:10.1039/C2JM34087A 